\title{
MARKET EFFICIENCY, FINANCIAL INTEGRATION, AND SHOCK TRANSMISSION (EMPIRICAL EVIDENCE FROM D-8 ECONOMIES)
}

\author{
Muhammad Usman Khurram ', Kashif Hamid², Rana Shahid Imdad Akash ${ }^{3}$
}

\begin{abstract}
The specific purpose of the Developing-8 economies is to integrate the endeavours of each member countries to excel economic cooperation and facilitation among the Islamic countries to enhance the investment opportunities and not to put pressure on the geopolitical environment of the world. The purpose of this study is to visualize the market efficiency, financial integration, and shock transmission process in the D-8 Economies for the period from Jan 2011 to Dec 2016. Daily market data is taken for KSE, DSE, TSE, JCI, KLCI, ISE, EGX, and NSE equity markets. Unit Root Test, Serial Correlation Test, Runs Test, and Variance Ratio Test are used to test the market efficiency whereas Johansen Cointegration Test, Granger Causality Test, Vector Error Correction Model, and Impulse Response Test are used to test the financial integration and shock transmission. The performance of the Tehran stock market remained excellent during this study period. Mixed evidence is concluded regarding the market efficiency of D-8 equity markets. It is concluded that there exists a long-run relationship between KSE and DSE. Short-run relationship indicates that KSE has a significant positive short-run relationship with $\mathrm{JCl}$ and have a negative relationship with $\mathrm{KLCl}$. Negative asymmetric behaviour is more influential in the negatively skewed markets and negative shocks have a greater effect than the positive shocks. Hence it is concluded that investors can get benefit from the arbitrage process due to market inefficiencies and through the short selling process. There is a need to establish economic equilibrium through the arbitrage process where investors may enjoy the opportunities to excel more economic stream of benefits by noise and market reverting behaviour. The economic integration will increase the cooperation among these economies to establish more growth opportunities in the trade and corporate investments. The implication of the studies suggests and directs to enhance mutual interface and co-operation including Banking and Finance, Human and Social Development, Energy Sector, Development of Rural Population, Science and Technology, Health and Environment, and Agriculture Sector. Moreover, there is a dire need for restructuring the economic and financial bylaws that may ease the financial liberalization and to enhance the dynamics of trading actives among the D-8 economies.
\end{abstract}

Key words: market efficiency, financial integration, shock transmission, D-8 Economies, arbitrage process.

JEL Classification: F36, G14, G15

\section{Introduction}

Fama (1970) designed efficient market hypothesis $(\mathrm{EMH})$ theory and elaborated that present equity prices captivate rapidly the inflow of latest information, therefore, present prices totally replicate whole existing information and predictability is not possible. Classical EMH theory indicates three types of market efficiencies and each type have various implications about market dynamics. Weak form of Efficient Market Hypothesis elaborates that current stock prices are the reflection of all historical price information. Market efficiency mechanics elaborates the behaviour of an economy and the formalization of economic structure. Here one aspect elaborates that markets predictability may be seen through financial integration among the diversified financial markets due to bilateral trade, foreign direct investments, economic shocks, and financial contagion effect. Whereas financial integration is a process where cross-border markets or regional markets or economic block markets are depended or closely interlinked with one another. Such integration includes the sharing of common information and financial products among the

\footnotetext{
Corresponding author:

${ }^{1}$ Zhejiang University, China.

E-mail: usmankhurram@zju.edu.cn

${ }^{2}$ Institute of Business Management Sciences, University of Agriculture, Pakistan.

E-mail: kashif.boparai@hotmail.com

${ }^{3}$ University of the Punjab. Jhelum Campus, Pakistan.

E-mail: shahid.imdad@yahoo.com
} 
financial markets and institutions. A complex financial engineering model is required as regards to the equity markets, foreign direct investment, the flow of capital funds, and human capital to elaborate the mechanics of bilateral financial relationships. The adverse effect of high financial integration is financial contagion across the economies.

Developing 8 or $\mathrm{D}-8$ group is a joint economic collaboration of Islamic developing countries. This group includes Pakistan, Bangladesh, Iran, Indonesia, Malaysia, Turkey, Egypt, and Nigeria. The group was established on June 15, 1997, in Turkey (Istanbul). The major purpose of $\mathrm{D}-8$ economies is to provide better economic conditions, to create diversification opportunities, and to increase the trading activities.

The major areas of interface and co-operation include Banking and Finance, Human and Social Development, Energy Sector, Development of Rural Population, Science and Technology, Health and Environment, and Agriculture Sector. The specific purpose of the Developing- 8 economies is to integrate the endeavours of each member country, and not to put pressure on the geopolitical environment of the world. However, member countries will remain autonomous in their actions without any specific reservations from any other group member.

\section{Literature review}

\subsection{Market efficiency}

Fama (1970); Granger (1975); Hawawini (1984); Fama (1991); Lo (1997); Worthington and Higgs (2004); Hamid, Suleman, Shah and Akash (2010) comprehensively tested empirically the weak form of Efficient Market Hypothesis for developed and emerging equity markets in different time periods. They agreed that there exists empirical evidence regarding the support of the EMH theory. Stakic, Jovancai and Kapor (2016) tested the hypothesis of the financial market efficiency in Serbia; they evaluated weak form efficiency and hence concluded that random walk hypothesis prevails for the period 2006 to 2013 . They used a unit root test and runs test to identify the weak form of efficiency. Arshad, Rizvi, Ghani and Duasa (2016) evaluated the tremendous growth of emerging and developing markets and tested the Efficient Market Hypothesis (EMH) for OIC member countries. The OIC stock markets are suffering from a global presence and the market efficiency remained always a question mark but it is concluded that the market efficiency is improving over the past decade. In a recent development, Sukpitak and Hengpunya (2016) measured market efficiency through the DFA method. The result confirms that emerging markets are becoming more efficient. This implies that market capitalization has a significant influence on market efficiency. In a joint study of efficiency and long term relationship dynamics, Rounaghi and Zadeh (2016) examined the changes and presence of long-term relationship features between returns and volatility of London Stock Exchange and S\&P 500 through ARMA method. The results indicate that there exist long-run relationship and both markets are efficient and during the periods of boom and bust both market are financially stable. Rizvi and Arshad (2017) analysed Japanese stock market efficiency and integration through MGARCH and MFDFA techniques during different business cycles of the Japanese economy. The outcomes indicate that market efficiency is improving during the study period. The findings also confirm that every succeeding recession generates a break into the integration levels resulting in a decrease.

\subsection{Financial integration}

Chung and Liu (1994); Roca (1999); Sheng and Tu (2000); Ng (2002); Lamba (2005); Suchismita and Paramita (2006); Hoque (2007); Hasan and Durrani (2008) identified financial integration among emerging and developed economies and concluded that there exist long-run and short-run dynamics among the economies. In recent studies, Mendoza, Quadrini and R'ios-Rull (2009) concluded that there become imbalances in the international markets as a result of financial integration due to recent developments in the financial markets of different economies and financial liabilities have been reduced. Hamid and Hasan (2011) investigated the causal and dynamic linkage among Pakistan and various other emerging and developed economies and identified the existence of long-run relationship among the KSE, JCI, and BCI. Moreover, the short-run relationship is identified between KSE and SCI. Further, they identified that there exist opportunities of portfolio diversification across the markets. Almekinders, Fukuda, Mourmouras, Zhou and Zhou (2015) evaluated economic and financial integration among ASEAN's stock markets. Strong financial integration can increase the level of real incomes and convergence within the ASEAN and this element is justified. Anwar and Raza (2016) examined the behaviour of the markets and identified that the long-run relationship exists among the KSE-100 index and SSE and KLSE. Results identify that changes in KSE are due to its own. Al-Nasser and Hajilee (2016) examined financial integration among emerging economies of Brazil, Mexico, China, Turkey, and Russia and developed markets of the UK, the USA, and Germany for the period from January 2001 to December 2014. They concluded that there prevails short-run integration among the stock markets and long-run relation of emerging countries exists with Germany stock market return. Alotaibi and Mishra (2017) examined international financial integration among GCC equity markets by using time-varying international asset pricing model and DCC-GARCH methodology. It is concluded that there exists a broad 
degree of financial integration among GCC stock markets and no one of these markets seem to be under entire segmentation. They found that trade openness, financial market turnover, and oil revenue have a significant positive impact on financial integration among GCC stock markets. However, the international financial crisis has a significant negative impact on the GCC integration index. Jin and An (2016) used volatility impulse response (VIRF) approach and concluded that BRICS' and U.S. stock markets are affected by shocks and contagion effect due to the 2007-2009 global financial crisis. Such a degree of stock market reactions to such shocks varies from one market to another and this element is dependent upon the level of economic integration.

\section{Data and methodology}

Daily data has been taken for stock market indices for the period from Jan 2011 to Dec 2016 for developing eight countries group. D-8 countries include Pakistan, Iran, Turkey, Nigeria, Bangladesh, Indonesia, Malaysia, and Egypt. To test the market efficiency and financial integration, we employed the following tests.

\subsection{Tests for market efficiency}

\subsubsection{Unit root test}

To visualize the presence of unit root in the financial time series, we used the Augmented Dickey-Fuller (ADF) test. The mathematical expression is narrated as below.

$$
\begin{aligned}
& \Delta \mathrm{SP}_{\mathrm{t}}=\gamma_{0}+\lambda_{1}+\lambda_{0} \mathrm{SP}_{\mathrm{t}-1}+\sum_{t=1}^{p} \phi_{\mathrm{q}} \Delta \mathrm{SP}_{\mathrm{qt}-1}+\epsilon_{\mathrm{t}} \\
& S P_{t}=\text { Stock Price at the time } t . \\
& \Delta S P_{t}=\text { Change in stock price at time. }
\end{aligned}
$$

\subsubsection{Serial correlation of returns}

Serial correlation elaborates that if the stock returns have no correlation at each lead and lag level then random walk exists in a particular time series. Combined hypothesis indicates if serial coefficients $\phi$ and $(t)$ are equivalent to zero all together, we therefore perform $Q_{\text {Box-Pierce }}$ statistics.

$$
Q_{B-P}=n \sum_{t=1}^{\mathrm{m}} \phi(t)
$$

\section{Whereas}

$\mathrm{Q}_{\text {Box-Pierce }}=$ Asymptotically distributed due chi-square $\left(\chi^{2}\right)$ at $m$ degrees of freedom.

$\mathrm{n}=$ total strength of observations.

$\mathrm{m}=$ maximum lag.

\subsubsection{Runs test}

To test the autonomy of the price variations, we deployed a runs test. There are two approaches that we can take into consideration, firstly take the positive returns $(+)$ where Return $>0$ and secondly a negative return (-) where Return $<0$ with respect to the average return. It is a non-parametric test because it does not assume the normal distribution of the return series. If returns are following a random walk hypothesis then the actual number of runs $(\lambda)$ should be closest to the expected number of runs $\left(\mu_{\lambda}\right)$.

Let + SR show total positive return (+) and $-S R$ show total negative returns $(-)$ for the given sample.

$$
d=\frac{\lambda-\mu_{\lambda}}{\sigma_{\lambda}} \approx \mathrm{N}(0,1)
$$

Where

$$
\mu_{\lambda}=\frac{2 S R_{+} S R_{-}}{S R}+1 \text { and } \sigma_{\lambda}=\sqrt{\frac{2 S R_{+} S R_{-}\left(2 S R_{+} S R_{-}-S R\right)}{S R^{2}(S R-1)}}
$$

\subsubsection{Variance ratio test}

According to Lo and MacKinlay (1988), if Rt follows a random walk then

$$
\text { Variance Ratio }(g)=\frac{\sigma^{2}(g)}{\sigma^{2}(1)}
$$

$\sigma^{2}(\mathrm{~g})=1 /$ gth variance of the $\mathrm{g}$-differences

$$
\text { whereas } \sigma^{2}(g)=\frac{1}{i} \sum_{t=g}^{m g}\left(\text { Return }_{\mathrm{t}}-\text { Return }_{\mathrm{t}-1}-\mathrm{g} \hat{\mu}\right)^{2}
$$

$\sigma^{2}(1)=$ Variance of the first differences

$$
\text { Whereas } \sigma^{2}(1)=\frac{1}{(m g-1)} \sum_{t=1}^{m g}\left(\operatorname{Return}_{\mathrm{t}}-\operatorname{Return}_{\mathrm{t}-1}-\hat{\mu}\right)^{2}(7)
$$

$\mathrm{H}_{0}=V R(\mathrm{~g})$ should move towards unity. Where $i=g(m g-g+1)\left[1-\frac{j}{m g}\right]$ and $\hat{\mu}$ indicate the
mean value of the sample.

If the homoscedastic element is assumed for incremental shocks, then we have

$$
Z(g)=\frac{V R(g)-1}{\eta_{o}(g)} \approx N(0,1)
$$

The lag difference $2,4,8,12,16$ is taken to test the random walk hypothesis.

\subsection{Test for financial integration}

The techniques used to test financial integration are the following:

\subsubsection{Johansen cointegration test}

Vector autoregressive (VAR) model is examined thorough Johansson procedure where $S I_{t}$ is an $(\mathrm{n} \times 1)$ vector of set of variables which are integrated at I (1) order and data must be non-stationary; this expression for the VAR equation is expressed as below.

$$
S I_{t}=\gamma+\sum_{j=1}^{m-1} \theta_{j} S I_{t-1}+\omega S I_{t-j}+\varepsilon_{t}
$$

Where

$\mathrm{SI}_{\mathrm{t}}=$ Stock indices at time $\mathrm{t}$.

$\theta$ and $\omega=$ Matrix of parameters

$\mathrm{m}=$ the number of lags

$\varepsilon_{t}=(\mathrm{n} \times 1)$ vector of innovations.

It is necessary to identify the long-run relationship; at least one cointegration relationship must exist. For the further detection of a number of co-integrating vectors, there are two likelihood ratios as expressed by the Johansen cointegration approach. 


$$
\begin{aligned}
& J_{\text {trace }}=-T \sum_{j=s+1}^{n} \ln \left(1-\lambda_{j}\right) \\
& J_{\max }=-T \ln \left(1-\lambda_{j},+1\right)
\end{aligned}
$$

Where,

$\mathrm{T}=$ sample size

$\lambda_{j}$ is the $j^{\text {th }}$ highest canonical correlation. The Trace test and Maximum Eigen value examines the $\mathrm{H}_{\mathrm{o}}$ of $s$ and $s+1$ co-integrating vectors respectively against the $\mathrm{H}_{1}$ of $n$ co-integrating vectors (Hjalmarsson and Osterholm, 2010).

\subsubsection{Granger causality test}

Granger (1969) used a VAR model to identify the direction of the long-run lead-lag relationship between the markets. The test follows the pairwise causal relationship from Market A to Market B and then from Market B to A. The regression equation is arranged in this manner.

$$
\begin{aligned}
& \Delta S I A_{t}=\sum_{i=1}^{m} \lambda_{i} \Delta S I A_{t-1}+\sum_{i=1}^{m} \phi_{i} \Delta S I B_{t-i}+\varepsilon_{t} \\
& \Delta S I B_{t}=\sum^{m} \lambda_{i} \Delta S I B_{t-1}+\sum^{m} \phi_{i} \Delta S I A_{t-i}+\varepsilon_{t} \\
& \Delta S I A_{\mathrm{t}}=\text { Change in stock market A } \\
& \Delta S I B_{\mathrm{t}}=\text { Change in stock market B } \\
& \lambda \text { and } \phi \text { are the coefficients. }
\end{aligned}
$$

\subsubsection{Error correction model}

If the set of 1(1) variable is co-integrated as stated by Granger representation theorem, then wehave the following Vector Error Correction (VECM) representation.

$$
\begin{aligned}
& \Delta S I A_{t}=u+\delta_{t}+\pi S I A_{t-1}+\sum_{i=1}^{m} \lambda_{i} \Delta S I A_{t-i}+\varepsilon_{t} \\
& \text { Where } \pi=-\left(\mathrm{I}_{\mathrm{m}}-\mathrm{P}_{1}-\mathrm{P}_{2}-\cdot-\cdot-\cdot---\mathrm{P}_{\mathrm{p}}\right) \\
& \text { and } \lambda_{\mathrm{i}}=-\left(\mathrm{P}_{\mathrm{i}+1}+\mathrm{P}_{\mathrm{i}+2}+-\ldots \ldots \ldots \ldots \ldots . . .\right.
\end{aligned}
$$

The VECM representation is essentially a VAR process districting with short-term parameter $\lambda_{\mathrm{i}}$ and the extra term $\pi S I A_{t-1}$ where $\pi$ is a matrix of $(\mathrm{m} \times \mathrm{m})$. Differenced VAR restriction binds the individual series of the vector
$S I A_{t}$ together and makes certain to the system returns for its long-run equilibrium (Banerjee et al, 1993).

\subsubsection{Impulse response test}

The excellent manner to explain the implications for price transmission, causality element is adjusted to visualize the time trail of prices after the exogenous shocks, which are known as impulse response behaviour (Vavra and Goodwin, 2005). Impulse response function pursues the impact of one SD or one unit shock to one of the endogenous variables on recent and future values over various time horizons (Rahman and Shahbaz, 2013).

\section{Results and discussion}

D-8 economies are discussed in this paper. Data is taken for the period January 2011 to December 2016 for the equity markets of Pakistan, Bangladesh, Iran, Indonesia, Malaysia, Turkey, Egypt, and Nigeria. Daily observations are taken for the analysis purpose to visualize the market efficiency and market integration on high-frequency data during this period. These markets are highly volatile as seen in the recent decade.

Figure 1 indicates the behaviour of market indices in a collaborative manner.

Table 1 indicates the descriptive statistics for the returns of the D-8 equity markets. Daily returns of all the equity markets are negatively skewed except Tehran Stock Exchange and Nigerian Stock Market, which reflects that large negative returns are greater than positive returns. Negative asymmetric behaviour is more influential in the negatively skewed markets. Negative shocks have a greater effect than positive shocks. The kurtosis value for Dhaka Stock Market and Egypt Stock Market has higher positive values, which indicate that distributions of returns are leptokurtic and show higher peaks. The Tehran stock market has $0.099 \%$ return with 0.0075 volatility while the Karachi stock market has $0.095 \%$ with 0.00879 volatility.

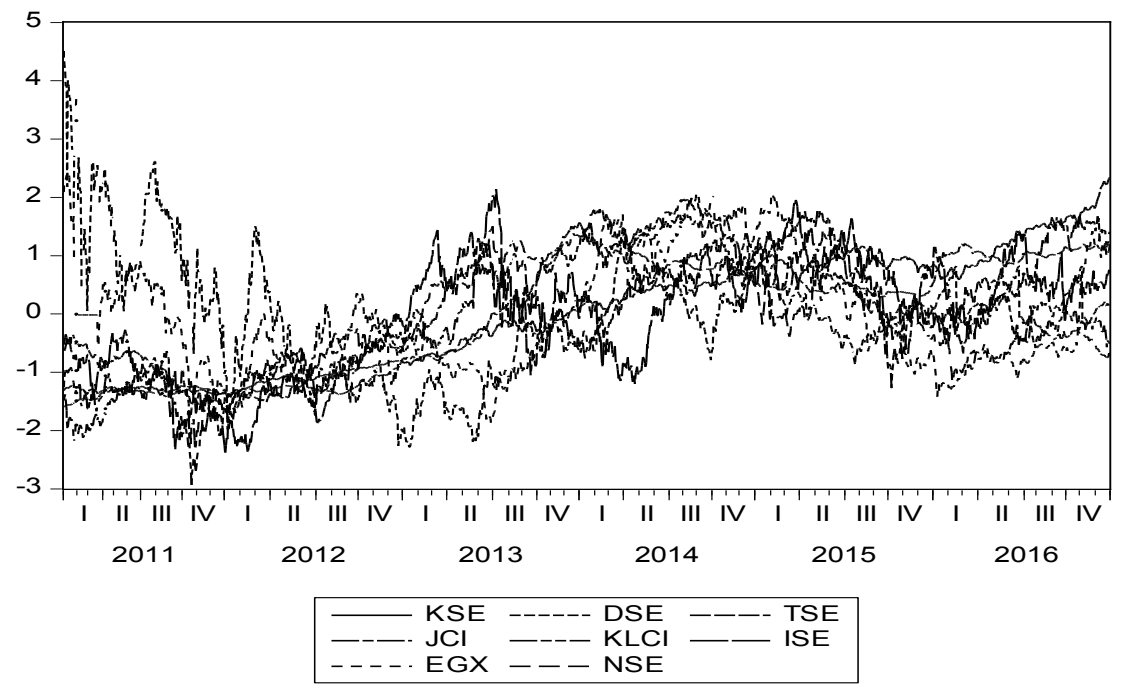

Figure 1. The Trend of D-8 Equity Market for Jan 2011 to Dec 2016 
The performance of the Tehran stock market remained excellent during this period in the set of D-8 economies. The Jarque-Bera test indicates the normality behaviour of all the stock returns.

\subsection{Market efficiency}

We used serial autocorrelation and Ljung-Box Q-statistics to test the randomness of returns. If, the $\mathrm{HO}=0$, may be rejected at 0.05 level of significance. Here KSE returns are indicating that the P-value < 0.05 of the Q-Statistics, Therefore, it is inferred from the Table 2 results that returns behaviour is predictable because this element indicates that weak form of market efficiency does not hold for this selected period. The null hypothesis is rejected for all markets except Istanbul Stock Market. Hence, it is concluded that ISE is an efficient market from this test point of view.

Unit Root Test is used to test the stationarity of the data. Random walk hypothesis assumes that the log price should have a unit root, whereas the change or returns series must follow the stationarity. Augmented Dickey-Fuller test (1981) and Phillips-Perron test (1988) are used to test the time series stationarity. Table 3 indicates that the time series is non-stationary at the order $\mathrm{I}(0)$ and becomes stationary at the order $\mathrm{I}(1)$ at $1 \%$ and $5 \%$ level of significance respectively.

Table 4.1 indicates that runs test statistics regarding the consecutive prices changes with the identical signs in the series. The null hypothesis indicates that the succeeding price changes move randomly and are not dependent. According to results, the return behaviour of KSE, TSE, KLCI, EGX and NSE are following random behaviour.

Runs test for Table 4.2 indicates that the total cases of runs are significantly less than the expected number of runs for all the countries and the KSE, TSE, KLCI, EGX, and NSE at $\mathrm{J}=$ Mean Value as well as $\mathrm{J}=0$ have lower number of runs against total number of cases and this phenomenon rejects the random walk hypothesis and narrates that these markets follow a weak form of efficiency.
Further, according to Lo and MacKinlay (1988), the variance ratio test is used to test the random walk hypothesis in a more modern way. It is inferred from this statistical test that if the variance ratio test statistics $>1$, the financial time series will be positively associated. The standardized VR test statistics for $\mathrm{z}(\mathrm{k})$ is significant at $\mathrm{J}$ $=2, \mathrm{~J}=4, \mathrm{~J}=8, \mathrm{~J}=12$ and $\mathrm{J}=16$ for all markets. According to Table 5 , the variance ratio indicates that the equity markets of D-8 countries are efficient based on daily return for the period of 2011-2016. Lo and MacKinlay (1988) identified that the acceptance or rejection of the Random Walk Hypothesis doesn't need to mean that the stock markets are efficient or inefficient respectively in actual spirit because the findings are based on a sample. When financial markets are closely linked together either neighbourly, regionally or globally in economic matters, it is called financial integration.

To test the financial integration, we deployed a correlation test, Granger causality test, consecration test, error correction model, and impulse response behaviour. Table 6 indicates that no market has a significant correlation with each other. All markets are behaving independently but directions of market behaviour are different as KSE market has a positive degree of association with DSE, JCI, and EXG but have a negative degree of relationship to TSE, ISE, and NSE. However, DSE has a negative association with EGX and positive association with ISE while TSE is negatively linked to the JCI, EGX, and NSE. KLCI and ISE are negatively related. However, ISE is negatively related to EGX and NSE.

Table 7 indicates that KSE returns lead to the DSE returns significantly. EGX Granger causes to the KSE. JCI Granger causes to DSE whereas DSE Granger causes to JCI, KLCI to TSE, KLCI to JCI, and JCI to KLCI, ISE to KLCI.

According to Table 8, trace statistics for cointegration indicates that there exist two co-integrating vectors among these economies.

According to Table 9, maximum eigenvalue indicates that no co-integrating vectors exist in between the D-8 Economies.

Table 1

Descriptive Statistics of the D-8 Returns

\begin{tabular}{|l|c|c|c|c|c|c|c|c|}
\hline & $\Delta$ KSE & $\Delta$ DSE & $\Delta$ TSE & $\Delta$ JCI & $\Delta$ KLCI & $\Delta$ ISE & $\Delta$ EGX & $\Delta$ NSE \\
\hline Mean & 0.0009 & -0.0003 & 0.0001 & 0.0002 & 0.00004 & 0.0001 & -0.00006 & -0.00001 \\
\hline Median & 0.0001 & 0.0000 & 0.0003 & 0.0010 & 0.00017 & 0.0007 & 0.0009 & -0.00026 \\
\hline Maximum & 0.0442 & 0.1503 & 0.0353 & 0.0465 & 0.0332 & 0.0624 & 0.0729 & 0.07985 \\
\hline Minimum & -0.0456 & -0.1601 & -0.0567 & -0.0930 & -0.0274 & -0.1106 & -0.1508 & -0.0435 \\
\hline Std. Dev. & 0.0088 & 0.0171 & 0.0076 & 0.0111 & 0.0059 & 0.0148 & 0.0147 & 0.0091 \\
\hline Skewness & -0.3388 & -1.2496 & 0.1574 & -0.8278 & -0.2662 & -0.6057 & -1.3178 & 0.2791 \\
\hline Kurtosis & 5.7076 & 23.079 & 6.8305 & 9.1620 & 5.6438 & 7.0565 & 15.6589 & 8.9657 \\
\hline Jarque-Bera & 474.86 & 24958.34 & 900.46 & 2481.67 & 443.34 & 1092.51 & 10191.90 & 2188.48 \\
\hline Probability & 0.0000 & 0.0000 & 0.0000 & 0.0000 & 0.0000 & 0.0000 & 0.0000 & 0.0000 \\
\hline Sum & 1.3949 & -0.3854 & 1.4479 & 0.3327 & 0.0573 & 0.1612 & -0.0869 & -0.0164 \\
\hline Sum Sq. Dev. & 0.1129 & 0.4292 & 0.0831 & 0.1803 & 0.0507 & 0.3201 & 0.3154 & 0.1454 \\
\hline Observations & 1463 & 1463 & 1463 & 1463 & 1463 & 1463 & 1463 & 1463 \\
\hline
\end{tabular}


Vol. 5, No. 4, 2019

Baltic Journal of Economic Studies

Table 2

Serial Correlation Coefficients and Q-Statistics for Returns

\begin{tabular}{|c|c|c|c|c|c|c|c|c|c|c|c|}
\hline & Period & 1 & 2 & 3 & 4 & 5 & 6 & 7 & 8 & 9 & 10 \\
\hline \multirow[t]{4}{*}{ KSE } & AC & 0.15 & 0.03 & -0.01 & 0.05 & -0.02 & -0.01 & -0.03 & 0.00 & 0.00 & 0.02 \\
\hline & PAC & 0.15 & 0.01 & -0.02 & 0.06 & -0.03 & 0.00 & -0.03 & 0.00 & 0.01 & 0.02 \\
\hline & Q-Stat & 31.12 & 32.25 & 32.40 & 36.63 & 37.11 & 37.16 & 38.45 & 38.47 & 38.49 & 39.01 \\
\hline & Prob & 0.00 & 0.00 & 0.00 & 0.00 & 0.00 & 0.00 & 0.00 & 0.00 & 0.00 & 0.00 \\
\hline \multirow[t]{4}{*}{ DSE } & $\mathrm{AC}$ & -0.07 & 0.01 & -0.01 & -0.04 & 0.04 & 0.03 & -0.05 & 0.07 & -0.04 & 0.01 \\
\hline & PAC & -0.07 & 0.00 & -0.01 & -0.05 & 0.03 & 0.03 & -0.04 & 0.07 & -0.02 & 0.00 \\
\hline & Q-Stat & 7.09 & 7.20 & 7.41 & 10.16 & 12.20 & 13.26 & 16.31 & 24.27 & 26.23 & 26.34 \\
\hline & Prob & 0.01 & 0.03 & 0.06 & 0.04 & 0.03 & 0.04 & 0.02 & 0.00 & 0.00 & 0.00 \\
\hline \multirow[t]{4}{*}{ TSE } & $\mathrm{AC}$ & 0.35 & 0.13 & 0.15 & 0.12 & 0.13 & 0.06 & 0.04 & 0.05 & 0.03 & 0.09 \\
\hline & PAC & 0.35 & 0.01 & 0.11 & 0.04 & 0.08 & -0.03 & 0.01 & 0.01 & -0.01 & 0.08 \\
\hline & Q-Stat & 179.21 & 204.53 & 236.08 & 257.68 & 282.33 & 287.67 & 290.28 & 293.37 & 294.30 & 306.22 \\
\hline & Prob & 0.00 & 0.00 & 0.00 & 0.00 & 0.00 & 0.00 & 0.00 & 0.00 & 0.00 & 0.00 \\
\hline \multirow[t]{4}{*}{ JCI } & $\mathrm{AC}$ & 0.05 & 0.00 & -0.14 & -0.09 & 0.01 & -0.06 & 0.09 & 0.01 & 0.03 & 0.04 \\
\hline & PAC & 0.05 & -0.01 & -0.14 & -0.07 & 0.01 & -0.09 & 0.08 & 0.00 & 0.01 & 0.06 \\
\hline & Q-Stat & 4.19 & 4.20 & 30.90 & 41.78 & 41.82 & 47.82 & 59.18 & 59.44 & 60.98 & 63.88 \\
\hline & Prob & 0.04 & 0.12 & 0.00 & 0.00 & 0.00 & 0.00 & 0.00 & 0.00 & 0.00 & 0.00 \\
\hline \multirow[t]{4}{*}{ KLCI } & $\mathrm{AC}$ & 0.09 & 0.04 & -0.03 & -0.02 & -0.02 & -0.02 & -0.05 & 0.01 & 0.02 & $\begin{array}{l}-0.02 \\
\end{array}$ \\
\hline & PAC & 0.09 & 0.03 & -0.04 & -0.02 & -0.02 & -0.01 & -0.04 & 0.02 & 0.02 & -0.03 \\
\hline & Q-Stat & 11.98 & 14.21 & 15.44 & 16.26 & 17.02 & 17.47 & 20.44 & 20.67 & 21.05 & 21.87 \\
\hline & Prob & 0.00 & 0.00 & 0.00 & 0.00 & 0.00 & 0.01 & 0.01 & 0.01 & 0.01 & 0.02 \\
\hline \multirow[t]{4}{*}{ ISE } & $\mathrm{AC}$ & -0.02 & 0.03 & 0.05 & -0.04 & 0.00 & -0.04 & -0.03 & 0.00 & -0.04 & 0.04 \\
\hline & PAC & -0.02 & 0.03 & 0.05 & -0.04 & -0.01 & -0.04 & -0.03 & 0.00 & -0.04 & 0.04 \\
\hline & Q-Stat & 0.80 & 2.43 & 5.38 & 7.52 & 7.54 & 9.73 & 11.09 & 11.11 & 13.62 & 15.80 \\
\hline & Prob & 0.37 & 0.30 & 0.15 & 0.11 & 0.18 & 0.14 & 0.14 & 0.20 & 0.14 & 0.11 \\
\hline \multirow[t]{4}{*}{ EGX } & $\mathrm{AC}$ & 0.23 & 0.03 & 0.08 & 0.03 & 0.06 & 0.03 & -0.02 & 0.04 & -0.02 & -0.02 \\
\hline & PAC & 0.23 & -0.03 & 0.08 & -0.01 & 0.05 & 0.00 & -0.03 & 0.04 & -0.04 & 0.00 \\
\hline & Q-Stat & 77.26 & 78.20 & 86.91 & 88.33 & 92.86 & 94.24 & 94.62 & 96.57 & 96.97 & 97.42 \\
\hline & Prob & 0.00 & 0.00 & 0.00 & 0.00 & 0.00 & 0.00 & 0.00 & 0.00 & 0.00 & 0.00 \\
\hline \multirow[t]{4}{*}{ NSE } & AC & 0.33 & 0.08 & -0.02 & 0.03 & 0.02 & -0.05 & -0.06 & -0.05 & 0.01 & -0.02 \\
\hline & PAC & 0.33 & -0.04 & -0.03 & 0.05 & -0.01 & -0.07 & -0.02 & -0.02 & 0.03 & -0.03 \\
\hline & Q-Stat & 162.82 & 171.56 & 171.93 & 173.11 & 173.61 & 177.25 & 182.79 & 186.03 & 186.19 & 186.53 \\
\hline & Prob & 0.00 & 0.00 & 0.00 & 0.00 & 0.00 & 0.00 & 0.00 & 0.00 & 0.00 & 0.00 \\
\hline
\end{tabular}

Significant at $\mathrm{p}<0.05$

Table 3

Unit Root Test

\begin{tabular}{|l|c|c|c|c|}
\hline $\begin{array}{c}\text { Equity Markets } \\
\text { Return }\end{array}$ & $\begin{array}{c}\text { Augmented Dicky-Fuller } \\
\text { Test at Level }\end{array}$ & $\begin{array}{c}\text { Augmented Dicky-Fuller } \\
\text { Test at 1st Difference }\end{array}$ & Phillips-Perron Test at Level & $\begin{array}{c}\text { Phillips-Perron Test at 1st } \\
\text { Difference }\end{array}$ \\
\hline$\Delta$ KSE & -33.0592 & -16.1861 & -33.1077 & -435.59 \\
\hline$\Delta$ DSE & -40.9804 & -19.3748 & -41.0281 & -464.592 \\
\hline$\Delta$ TSE & -16.7887 & -19.1831 & -28.7495 & -389.933 \\
\hline$\Delta$ JCI & -22.4491 & -21.5621 & -36.318 & -581.741 \\
\hline$\Delta$ KLCI & -34.9465 & -20.0327 & -34.8293 & -355.354 \\
\hline$\Delta$ ISE & -39.1166 & -19.6035 & -39.1201 & -555.932 \\
\hline$\Delta$ EGX & -30.2487 & -19.0881 & -30.5829 & -379.253 \\
\hline$\Delta$ NSE & -27.0247 & -17.4671 & -26.3578 & -325.309 \\
\hline
\end{tabular}

Table 3.1

\section{Critical Values}

\begin{tabular}{|l|c|c|c|}
\hline \multicolumn{1}{|c|}{ Probabilities } & $1 \%$ & $5 \%$ & $10 \%$ \\
\hline ADF at level & -3.43462 & -2.86331 & -2.56776 \\
\hline ADF at first difference & -3.43467 & -2.86334 & -2.56777 \\
\hline PP at level & -3.43462 & -2.86331 & -2.56776 \\
\hline PP at difference & -3.43462 & -2.86331 & -2.56776 \\
\hline
\end{tabular}


Table 4.1

Runs Test With J=Mean Value

\begin{tabular}{|l|c|c|c|c|c|c|c|c|}
\hline & $\Delta$ KSE & $\Delta$ DSE & $\Delta$ TSE & $\Delta$ JCI & $\Delta$ KLCI & $\Delta$ ISE & $\Delta$ EGX & $\Delta$ NSE \\
\hline $\mathrm{J}=$ mean value & .00095 & -.00026 & .00099 & .00023 & .00004 & .00011 & -.00006 & -.00001 \\
\hline Cases < Test Value & 729 & 566 & 840 & 669 & 712 & 702 & 654 & 756 \\
\hline Cases >= Test Value & 734 & 897 & 623 & 794 & 751 & 761 & 809 & 707 \\
\hline Total Cases & 1463 & 1463 & 1463 & 1463 & 1463 & 1463 & 1463 & 1463 \\
\hline Number of Runs & 623 & 681 & 504 & 747 & 668 & 744 & 635 & 590 \\
\hline $\mathrm{Z}$ & -5.727 & -.775 & -11.360 & 1.045 & -3.349 & .665 & -4.723 & -7.419 \\
\hline p-value & .000 & .438 & .000 & .296 & .001 & .506 & .000 & .000 \\
\hline
\end{tabular}

Significant at $\mathrm{p}<0.05$

Table 4.2

Runs Test with $\mathbf{J}=\mathbf{0}$

\begin{tabular}{|l|c|c|c|c|c|c|c|c|}
\hline & $\Delta$ KSE & $\Delta$ DSE & $\Delta$ TSE & $\Delta$ JCI & $\Delta$ KLCI & $\Delta$ ISE & $\Delta$ EGX & $\Delta$ NSE \\
\hline $\mathrm{J}=0$ & .00097 & 0.00000 & .00028 & .00103 & .00017 & .00071 & .00085 & -.00026 \\
\hline Cases < Test Value & 731 & 583 & 731 & 731 & 731 & 731 & 731 & 731 \\
\hline Cases >= Test Value & 732 & 880 & 732 & 732 & 732 & 732 & 732 & 732 \\
\hline Total Cases & 1463 & 1463 & 1463 & 1463 & 1463 & 1463 & 1463 & 1463 \\
\hline Number of Runs & 621 & 699 & 550 & 751 & 674 & 746 & 635 & 586 \\
\hline Z & -5.832 & -.183 & -9.546 & .968 & -3.060 & .706 & -5.100 & -7.663 \\
\hline p-value & .000 & .855 & .000 & .333 & .002 & .480 & .000 & .000 \\
\hline
\end{tabular}

Significant at $\mathrm{p}<0.05$

Table 5

Variance Ratio Test at Return Series

\begin{tabular}{|c|c|c|c|c|c|c|}
\hline $\begin{array}{c}\text { Equity Markets } \\
\text { Return }\end{array}$ & Period (k) & 2 & 4 & 8 & 12 & 16 \\
\hline \multirow[t]{3}{*}{$\Delta \mathrm{KSE}$} & $\mathrm{VR}(\mathrm{k})$ & 0.5699 & 0.2777 & 0.1478 & 0.1044 & 0.0755 \\
\hline & $\mathrm{z}(\mathrm{k})$ & -10.21 & -9.9250 & -8.1735 & -7.1368 & -6.4754 \\
\hline & Probability & 0 & 0 & 0 & 0 & 0 \\
\hline \multirow[t]{3}{*}{$\triangle \mathrm{DSE}$} & $\mathrm{VR}(\mathrm{k})$ & 0.4641 & 0.2447 & 0.1033 & 0.0764 & 0.0584 \\
\hline & $\mathrm{z}(\mathrm{k})$ & -5.6261 & -5.0087 & -4.5109 & -3.9414 & -3.5651 \\
\hline & Probability & 0 & 0 & 0 & 0.0001 & 0.0004 \\
\hline \multirow[t]{3}{*}{$\Delta \mathrm{TSE}$} & $\mathrm{VR}(\mathrm{k})$ & 0.6684 & 0.3386 & 0.1848 & 0.1204 & 0.0955 \\
\hline & $\mathrm{z}(\mathrm{k})$ & -6.2499 & -7.5644 & -6.7222 & -6.0709 & -5.5116 \\
\hline & Probability & 0 & 0 & 0 & 0 & 0 \\
\hline \multirow[t]{3}{*}{$\Delta \mathrm{JCI}$} & $\mathrm{VR}(\mathrm{k})$ & 0.5306 & 0.2873 & 0.1299 & 0.0855 & 0.0656 \\
\hline & $\mathrm{z}(\mathrm{k})$ & -9.5581 & -8.1681 & -6.8322 & -5.9151 & -5.2988 \\
\hline & Probability & 0 & 0 & 0 & 0 & 0 \\
\hline \multirow[t]{3}{*}{$\Delta \mathrm{KLCI}$} & $\mathrm{VR}(\mathrm{k})$ & 0.5286 & 0.2821 & 0.1363 & 0.0924 & 0.0713 \\
\hline & $\mathrm{z}(\mathrm{k})$ & -11.6762 & -10.1748 & -8.2989 & -7.06509 & -6.2648 \\
\hline & Probability & 0 & 0 & 0 & 0 & 0 \\
\hline \multirow[t]{3}{*}{$\Delta$ ISE } & $\mathrm{VR}(\mathrm{k})$ & 0.4727 & 0.2545 & 0.1227 & 0.0799 & 0.0632 \\
\hline & $\mathrm{z}(\mathrm{k})$ & -11.3552 & -9.4402 & -7.6665 & -6.6620 & -5.9451 \\
\hline & Probability & 0 & 0 & 0 & 0 & 0 \\
\hline \multirow[t]{3}{*}{$\Delta \mathrm{EGX}$} & $\mathrm{VR}(\mathrm{k})$ & 0.63337 & 0.3155 & 0.1575 & 0.1075 & 0.0782 \\
\hline & $\mathrm{z}(\mathrm{k})$ & -7.210498 & -7.2614 & -6.2522 & -5.6493 & -5.2708 \\
\hline & Probability & 0 & 0 & 0 & 0 & 0 \\
\hline \multirow[t]{3}{*}{$\Delta \mathrm{NSE}$} & $\mathrm{VR}(\mathrm{k})$ & 0.692067 & 0.3646 & 0.1974 & 0.1292 & 0.0907 \\
\hline & $\mathrm{z}(\mathrm{k})$ & -7.373055 & -8.5776 & -7.4522 & -6.7214 & -6.1818 \\
\hline & Probability & 0 & 0 & 0 & 0 & 0 \\
\hline
\end{tabular}

Significant at $\mathrm{p}<0.05$ 
Vol. 5, No. 4, 2019

Table 6

Correlation Matrix of Developing Eight (D-8) Equity Markets

\begin{tabular}{|l|c|c|c|c|c|c|c|c|}
\hline & $\Delta$ KSE & $\Delta$ DSE & $\Delta$ TSE & $\Delta$ JCI & $\Delta$ KLCI & $\Delta$ ISE & $\Delta$ EGX & $\Delta$ NSE \\
\hline$\Delta$ KSE & 1 & & & & & & & \\
\hline$\Delta$ DSE & 0.003 & 1 & & & & & & \\
\hline$\Delta$ TSE & -0.0284 & -0.0158 & 1 & & & & & \\
\hline$\Delta$ JCI & 0.0150 & 0.0044 & -0.0185 & 1 & & & \\
\hline$\Delta$ KLCI & 0.0076 & 0.0344 & 0.0697 & 0.0591 & 1 & & & \\
\hline$\Delta$ ISE & -0.0163 & 0.0085 & -0.0156 & -0.0088 & -0.0333 & 1 & & \\
\hline$\Delta$ EGX & 0.0223 & -0.0440 & -0.0050 & 0.0474 & 0.0603 & -0.0066 & 1 & \\
\hline$\Delta$ NSE & -0.0458 & -0.0217 & 0.0455 & -0.0050 & 0.0250 & -0.0395 & 0.0509 & 1 \\
\hline
\end{tabular}

Significant at $\mathrm{p}<0.05$

Table 7

Pairwise Granger Causality Tests

\begin{tabular}{|c|c|c|c|c|c|}
\hline \multicolumn{3}{|c|}{ Null Hypothesis: } & \multirow{2}{*}{$\begin{array}{l}\text { Obs. } \\
1461\end{array}$} & \multirow{2}{*}{$\begin{array}{c}\text { F-Statistic } \\
0.08701\end{array}$} & \multirow{2}{*}{$\begin{array}{c}\text { Prob. } \\
0.9167\end{array}$} \\
\hline$\Delta \mathrm{DSE}$ & $\longrightarrow$ & $\Delta \mathrm{KSE}$ & & & \\
\hline$\Delta \mathrm{KSE}$ & $\longrightarrow$ & $\Delta$ DSE & & 8.15382 & 0.0003 \\
\hline$\Delta$ TSE & $\longrightarrow$ & $\Delta \mathrm{KSE}$ & 1461 & 0.12211 & 0.8851 \\
\hline$\Delta \mathrm{KSE}$ & $\longrightarrow$ & $\Delta$ TSE & & 0.70599 & 0.4938 \\
\hline$\Delta \mathrm{JCI}$ & $\longrightarrow$ & $\Delta \mathrm{KSE}$ & 1461 & 1.46007 & 0.2326 \\
\hline$\Delta \mathrm{KSE}$ & $\longrightarrow$ & $\Delta \mathrm{JCI}$ & & 0.94862 & 0.3875 \\
\hline$\Delta \mathrm{KLCI}$ & $\longrightarrow$ & $\Delta \mathrm{KSE}$ & 1461 & 0.45832 & 0.6324 \\
\hline$\Delta \mathrm{KSE}$ & $\longrightarrow$ & $\Delta \mathrm{KLCI}$ & & 0.3644 & 0.6947 \\
\hline$\Delta$ ISE & $\longrightarrow$ & $\Delta \mathrm{KSE}$ & 1461 & 1.864 & 0.1554 \\
\hline$\Delta \mathrm{KSE}$ & $\longrightarrow$ & $\Delta$ ISE & & 0.31486 & 0.7299 \\
\hline$\Delta \mathrm{EGX}$ & $\longrightarrow$ & $\Delta \mathrm{KSE}$ & 1461 & 3.49343 & 0.0307 \\
\hline$\Delta \mathrm{KSE}$ & $\longrightarrow$ & $\Delta \mathrm{EGX}$ & & 2.06068 & 0.1277 \\
\hline$\Delta$ NSE & $\longrightarrow$ & $\Delta \mathrm{KSE}$ & 1461 & 0.15833 & 0.8536 \\
\hline$\Delta \mathrm{KSE}$ & $\longrightarrow$ & $\Delta$ NSE & & 0.76243 & 0.4667 \\
\hline$\Delta$ TSE & $\longrightarrow$ & $\Delta \mathrm{DSE}$ & 1461 & 2.04665 & 0.1295 \\
\hline$\Delta$ DSE & $\longrightarrow$ & $\Delta$ TSE & & 0.12605 & 0.8816 \\
\hline$\Delta \mathrm{JCI}$ & $\longrightarrow$ & $\Delta$ DSE & 1461 & 4.01466 & 0.0182 \\
\hline$\Delta \mathrm{DSE}$ & $\longrightarrow$ & $\Delta \mathrm{JCI}$ & & 5.9552 & 0.0027 \\
\hline$\Delta \mathrm{KLCI}$ & $\longrightarrow$ & $\Delta \mathrm{DSE}$ & 1461 & 1.4161 & 0.243 \\
\hline$\Delta$ DSE & $\longrightarrow$ & $\Delta \mathrm{KLCI}$ & & 0.81207 & 0.4441 \\
\hline$\Delta$ ISE & $\longrightarrow$ & $\Delta \mathrm{DSE}$ & 1461 & 1.11972 & 0.3267 \\
\hline$\Delta \mathrm{DSE}$ & $\longrightarrow$ & $\Delta$ ISE & & 1.56376 & 0.2097 \\
\hline$\Delta \mathrm{EGX}$ & $\longrightarrow$ & $\Delta$ DSE & 1461 & 0.16414 & 0.8486 \\
\hline$\Delta$ DSE & $\longrightarrow$ & $\Delta \mathrm{EGX}$ & & 1.9522 & 0.1423 \\
\hline$\Delta$ NSE & $\longrightarrow$ & $\Delta$ DSE & 1461 & 0.21553 & 0.8061 \\
\hline$\Delta \mathrm{DSE}$ & $\longrightarrow$ & $\Delta \mathrm{NSE}$ & & 0.27471 & 0.7598 \\
\hline$\Delta \mathrm{JCI}$ & $\longrightarrow$ & $\Delta$ TSE & 1461 & 0.63645 & 0.5293 \\
\hline$\Delta$ TSE & $\longrightarrow$ & $\Delta \mathrm{JCI}$ & & 1.35444 & 0.2584 \\
\hline$\Delta \mathrm{KLCI}$ & $\longrightarrow$ & $\Delta$ TSE & 1461 & 3.35197 & 0.0353 \\
\hline$\Delta$ TSE & $\longrightarrow$ & $\Delta \mathrm{KLCI}$ & & 0.10671 & 0.8988 \\
\hline$\Delta$ ISE & $\longrightarrow$ & $\Delta$ TSE & 1461 & 0.01042 & 0.9896 \\
\hline$\Delta \mathrm{TSE}$ & $\longrightarrow$ & $\Delta$ ISE & & 0.32909 & 0.7196 \\
\hline$\Delta \mathrm{EGX}$ & $\longrightarrow$ & $\Delta$ TSE & 1461 & 0.03709 & 0.9636 \\
\hline$\Delta$ TSE & $\longrightarrow$ & $\Delta \mathrm{EGX}$ & & 0.91619 & 0.4003 \\
\hline$\Delta$ NSE & $\longrightarrow$ & $\Delta$ TSE & 1461 & 0.8841 & 0.4133 \\
\hline$\Delta$ TSE & $\longrightarrow$ & $\Delta$ NSE & & 3.54746 & 0.029 \\
\hline$\Delta \mathrm{KLCI}$ & $\longrightarrow$ & $\Delta \mathrm{JCI}$ & 1461 & 7.16791 & 0.0008 \\
\hline$\Delta \mathrm{JCI}$ & $\longrightarrow$ & $\Delta \mathrm{KLCI}$ & & 5.5817 & 0.0038 \\
\hline
\end{tabular}




\begin{tabular}{|c|c|c|c|c|c|}
\hline \multicolumn{3}{|c|}{ Null Hypothesis: } & \multirow{2}{*}{$\begin{array}{l}\text { Obs. } \\
1461\end{array}$} & \multirow{2}{*}{$\begin{array}{c}\text { F-Statistic } \\
0.47372\end{array}$} & \multirow{2}{*}{$\begin{array}{l}\text { Prob. } \\
0.6228\end{array}$} \\
\hline$\Delta$ ISE & $\longrightarrow$ & $\Delta \mathrm{JCI}$ & & & \\
\hline$\Delta \mathrm{JCI}$ & $\longrightarrow$ & $\Delta$ ISE & & 0.33722 & 0.7138 \\
\hline$\Delta \mathrm{EGX}$ & $\longrightarrow$ & $\Delta \mathrm{JCI}$ & 1461 & 1.57722 & 0.2069 \\
\hline$\Delta \mathrm{JCI}$ & $\longrightarrow$ & $\Delta \mathrm{EGX}$ & & 0.55577 & 0.5738 \\
\hline$\Delta$ NSE & $\longrightarrow$ & $\Delta \mathrm{JCI}$ & 1461 & 0.67267 & 0.5105 \\
\hline$\Delta \mathrm{JCI}$ & $\longrightarrow$ & $\Delta$ NSE & & 0.26777 & 0.7651 \\
\hline$\Delta$ ISE & $\longrightarrow$ & $\Delta \mathrm{KLCI}$ & 1461 & 2.42099 & 0.0892 \\
\hline$\Delta \mathrm{KLCI}$ & $\longrightarrow$ & $\Delta$ ISE & & 0.03488 & 0.9657 \\
\hline$\Delta \mathrm{EGX}$ & $\rightarrow$ & $\Delta \mathrm{KLCI}$ & 1461 & 0.35025 & 0.7046 \\
\hline$\Delta \mathrm{KLCI}$ & $\rightarrow$ & $\Delta \mathrm{EGX}$ & & 0.69814 & 0.4977 \\
\hline$\Delta$ NSE & $\longrightarrow$ & $\Delta \mathrm{KLCI}$ & 1461 & 1.35915 & 0.2572 \\
\hline$\Delta \mathrm{KLCI}$ & $\longrightarrow$ & $\Delta$ NSE & & 0.32108 & 0.7254 \\
\hline$\Delta \mathrm{EGX}$ & $\longrightarrow$ & $\Delta$ ISE & 1461 & 1.72455 & 0.1786 \\
\hline$\Delta$ ISE & $\longrightarrow$ & $\Delta \mathrm{EGX}$ & & 0.49371 & 0.6105 \\
\hline$\Delta \mathrm{NSE}$ & $\longrightarrow$ & $\Delta$ ISE & 1461 & 1.79428 & 0.1666 \\
\hline$\Delta$ ISE & $\longrightarrow$ & $\Delta$ NSE & & 0.03948 & 0.9613 \\
\hline$\Delta \mathrm{NSE}$ & $\longrightarrow$ & $\Delta \mathrm{EGX}$ & 1461 & 1.00756 & 0.3654 \\
\hline$\Delta \mathrm{EGX}$ & $\longrightarrow$ & $\Delta$ NSE & & 0.7565 & 0.4695 \\
\hline
\end{tabular}

Significant at $\mathrm{p}<0.05$

Table 8

Cointegration Test -Trace Statistics

\begin{tabular}{|l|c|c|c|c|}
\hline \multicolumn{1}{|c|}{ No. of CE(s) } & Eigenvalue & Statistic & Critical Value & Prob.* $^{* * 1}$ \\
\hline None & 0.032426 & 177.9823 & 159.5297 & 0.0033 \\
\hline At most $1^{*}$ & 0.025724 & 129.8884 & 125.6154 & 0.0268 \\
\hline At most 2 & 0.022171 & 91.86609 & 95.75366 & 0.0899 \\
\hline At most 3 & 0.017932 & 59.15503 & 69.81889 & 0.2622 \\
\hline At most 4 & 0.014254 & 32.7544 & 47.85613 & 0.5704 \\
\hline At most 5 & 0.00552 & 11.80877 & 29.79707 & 0.9383 \\
\hline At most 6 & 0.002541 & 3.732788 & 15.49471 & 0.9239 \\
\hline At most 7 & 0.000137 & 0.020045 & 3.841466 & 0.8873 \\
\hline
\end{tabular}

Significant at $\mathrm{p}<0.05$

Table 9

Cointegration Test - Maximum Eigenvalue

\begin{tabular}{|l|c|c|c|c|}
\hline $\begin{array}{c}\text { Hypothesized } \\
\text { No. of CE(s) }\end{array}$ & Eigenvalue & $\begin{array}{c}\text { Max-Eigen } \\
\text { Statistic }\end{array}$ & $\begin{array}{c}0.05 \\
\text { Critical Value }\end{array}$ & Prob.** $^{* *}$ \\
\hline None & 0.032426 & 48.09387 & 52.36261 & 0.1284 \\
\hline At most 1 & 0.025724 & 38.02236 & 46.23142 & 0.2868 \\
\hline At most 2 & 0.022171 & 32.71106 & 40.07757 & 0.2656 \\
\hline At most 3 & 0.017932 & 26.40063 & 33.87687 & 0.2969 \\
\hline At most 4 & 0.014254 & 20.94564 & 27.58434 & 0.2795 \\
\hline At most 5 & 0.00552 & 8.075977 & 21.13162 & 0.899 \\
\hline At most 6 & 0.002541 & 3.712744 & 14.2646 & 0.8884 \\
\hline At most 7 & 0.000137 & 0.020045 & 3.841466 & 0.8873 \\
\hline
\end{tabular}

Significant at $\mathrm{p}<0.05$

Table 10

Bivariate Cointegration - Trace Statistics between KSE and DSE

\begin{tabular}{|l|c|c|c|c|}
\hline $\begin{array}{c}\text { Hypothesized } \\
\text { No. of CE(s) }\end{array}$ & Eigenvalue & $\begin{array}{c}\text { Trace } \\
\text { Statistic }\end{array}$ & $\begin{array}{c}0.05 \\
\text { Critical Value }\end{array}$ & Prob. $^{* *}$ \\
\hline None $^{*}$ & 0.014381 & 21.97608 & 15.49471 & 0.0046 \\
\hline At most 1 & 0.000577 & 0.84205 & 3.841466 & 0.3588 \\
\hline
\end{tabular}

Significant at $\mathrm{p}<0.05$ 
Vol. 5, No. 4, 2019

Table 11

Bivariate Cointegration - Max-Eigen Statistics between KSE and DSE

\begin{tabular}{|l|c|c|c|c|}
\hline $\begin{array}{c}\text { Hypothesized } \\
\text { No. of CE(s) }\end{array}$ & Eigenvalue & $\begin{array}{c}\text { Max-Eigen } \\
\text { Statistic }\end{array}$ & $\begin{array}{c}0.05 \\
\text { Critical Value }\end{array}$ & Prob.** $^{* *}$ \\
\hline None $^{*}$ & 0.014381 & 21.13403 & 14.2646 & 0.0035 \\
\hline At most 1 & 0.000577 & 0.84205 & 3.841466 & 0.3588 \\
\hline
\end{tabular}

Significant at $\mathrm{p}<0.05$

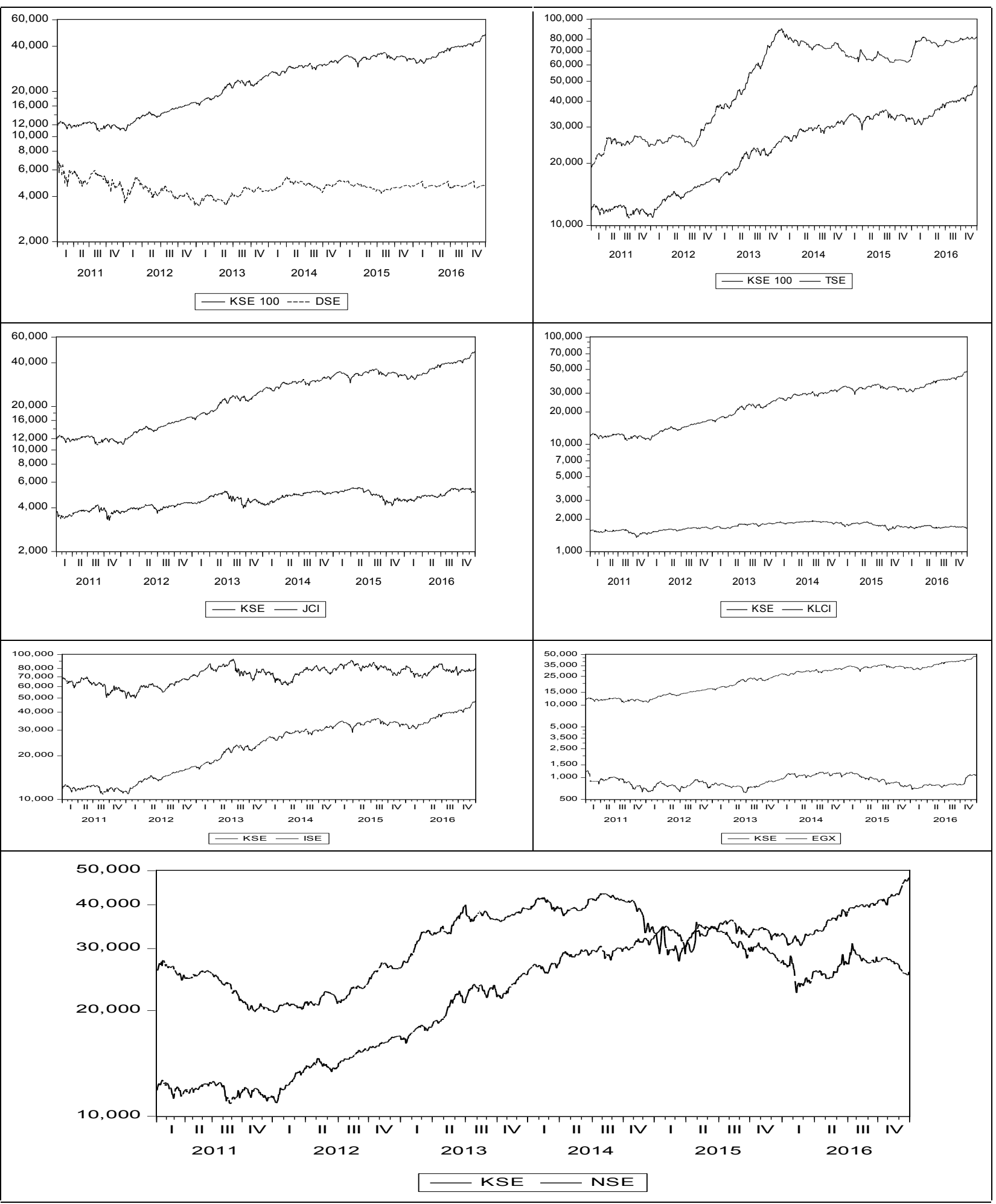

Figure 2. Co-movement of KSE with D-8 Economies 
Table 10 indicates the bivariate cointegration statistics between KSE and DSE and identified one co-integrated vector because trace statistics is greater the critical value at none level.

Table 11 indicates the bivariate cointegration statistics between KSE and DSE and identified no co-integrated vector because Max Eigen statistics is not greater than the critical value at none level.

The below Figure 2 is indicating the behaviour of KSE with other D-8 economies in a log-normal linear fashion.

Figure 3 indicates the impulse response behaviour and the impact of one shock on the economy at different lags and in how much time the shock is transmitted and is absorbed.
Table 12 indicates that KSE has a significant positive short-run relationship at lag 1 and lag 2 with JCI and have a negative relationship with KLCI. However, DSE has a positive relationship with KSE, as well at lag 1 and lag 2 , and has a negative significant relationship with KLCE at lag 1. TSE has a positive relationship with KLCI at lag 1. JCI has a negative relationship with KLCI, EGX, and NSE at lag 1 and lag 2 as well. KLCI has a negative relationship at lag 2 and a positive relationship with NSE at lag 1 and 2. ISE has a positive relationship with NSE at lag 1. EGX has a negative relationship with KLCI at lag 2 and negative relationship with JCI at lag 2 . NSE has a negative relationship with JCI at lag 1 and lag 2 and has a positive relationship with KLCI at lag 1 .

Response to Cholesky One S.D. Innovations \pm 2 S.E.

Response of KSE_RETURN to DSE_RETURN
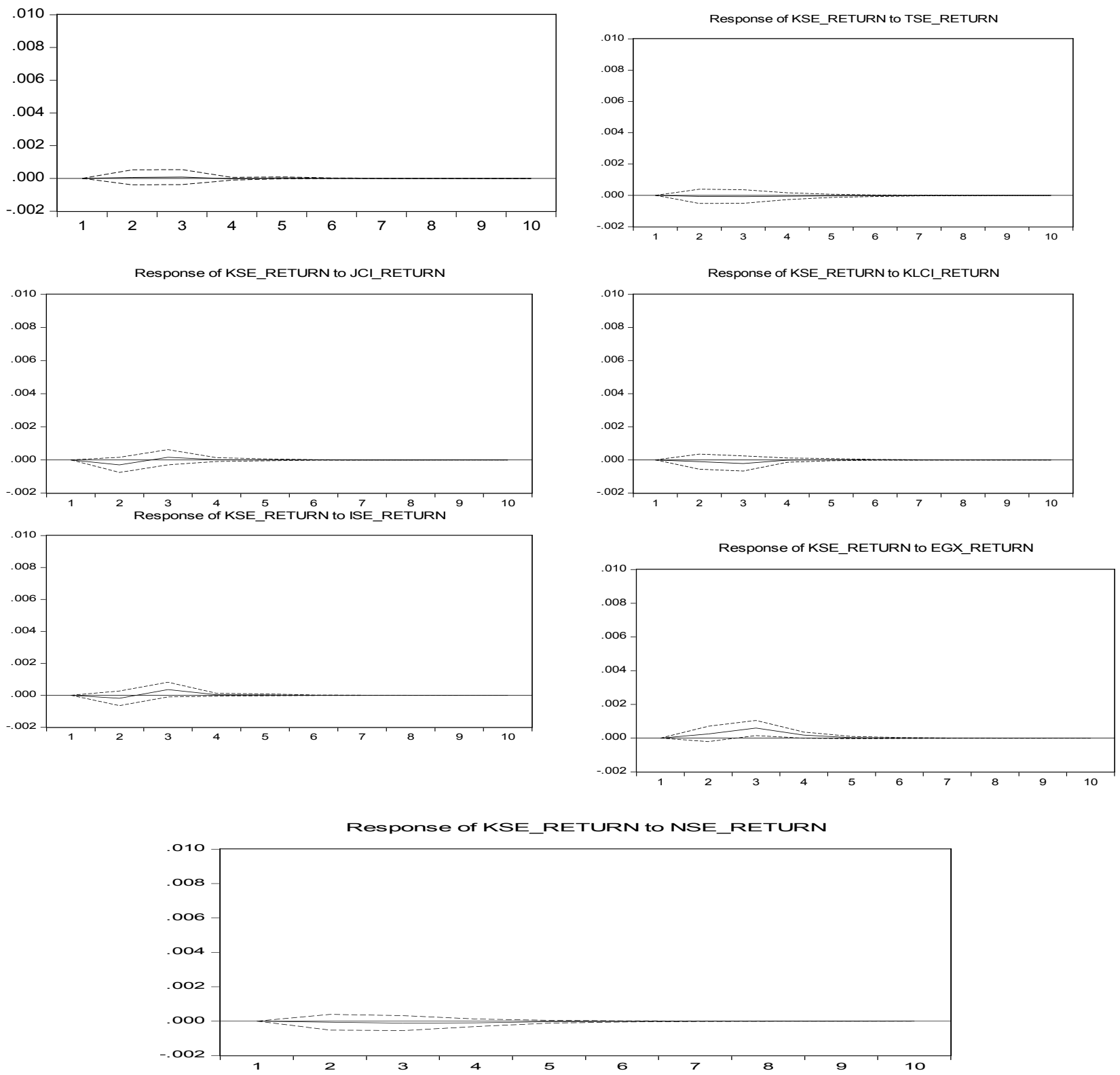

Figure 3. Impulse Response Behaviour of KSE to D-8 Economies 
Vol. 5, No. 4, 2019

Baltic Journal of Economic Studies

Table 12

Vector Error Correction Model

\begin{tabular}{|c|c|c|c|c|c|c|c|c|}
\hline $\begin{array}{c}\text { Error } \\
\text { Correction }\end{array}$ & $\Delta \mathrm{KSE}$ & $\Delta \mathrm{DSE}$ & $\Delta \mathrm{TSE}$ & $\Delta \mathrm{JCI}$ & $\Delta \mathrm{KLCI}$ & $\Delta \mathrm{ISE}$ & $\Delta \mathrm{EGX}$ & $\Delta \mathrm{NSE}$ \\
\hline \multirow[t]{3}{*}{ CointEq1 } & -0.038407 & -0.025489 & 0.008815 & -0.2522 & 0.03145 & -0.01151 & 0.03143 & 0.044 \\
\hline & -0.00962 & -0.01931 & -0.00752 & -0.01086 & -0.00647 & -0.01638 & -0.01547 & -0.01034 \\
\hline & {$[-3.99123]$} & {$[-1.31987]$} & {$[1.17204]$} & {$[-23.2200]$} & {$[4.85822]$} & {$[-0.70269]$} & {$[2.03119]$} & {$[4.25662]$} \\
\hline \multirow[t]{3}{*}{$\Delta \operatorname{KSE}(-1)$} & -0.523787 & 0.171608 & -0.015859 & 0.188413 & -0.023771 & 0.000677 & -0.072687 & 0.00037 \\
\hline & -0.02606 & -0.0523 & -0.02037 & -0.02942 & -0.01753 & -0.04437 & -0.04191 & -0.02799 \\
\hline & {$[-20.0979]$} & [3.28106] & {$[-0.77854]$} & {$[6.40512]$} & {$[-1.35581]$} & {$[0.01526]$} & {$[-1.73443]$} & {$[0.01305]$} \\
\hline \multirow[t]{3}{*}{$\Delta \mathrm{KSE}(-2)$} & -0.270181 & 0.122004 & 0.00947 & 0.089112 & -0.005245 & 0.061356 & 0.020199 & 0.00289 \\
\hline & -0.02544 & -0.05105 & -0.01988 & -0.02871 & -0.01711 & -0.04331 & -0.04091 & -0.02732 \\
\hline & {$[-10.6211]$} & {$[2.38985]$} & {$[0.47630]$} & {$[3.10364]$} & {$[-0.30651]$} & {$[1.41675]$} & {$[0.49380]$} & [0.10572] \\
\hline \multirow[t]{3}{*}{$\Delta \operatorname{DSE}(-1)$} & -0.006604 & -0.719747 & 0.002304 & -0.01072 & 0.004157 & -0.03595 & -0.022522 & -0.0034 \\
\hline & -0.01245 & -0.02498 & -0.00973 & -0.01405 & -0.00837 & -0.02119 & -0.02002 & -0.01337 \\
\hline & {$[-0.53053]$} & {$[-28.8132]$} & {$[0.23679]$} & {$[-0.76305]$} & {$[0.49643]$} & {$[-1.69644]$} & {$[-1.12525]$} & {$[-0.25431]$} \\
\hline \multirow[t]{3}{*}{$\Delta$ DSE $(-2)$} & 0.001466 & -0.340554 & 0.013729 & 0.008709 & 0.009004 & -0.00792 & -0.000143 & $3.78 \mathrm{E}-05$ \\
\hline & -0.01232 & -0.02473 & -0.00963 & -0.01391 & -0.00829 & -0.02098 & -0.01982 & -0.01324 \\
\hline & {$[0.11899]$} & {$[-13.7701]$} & {$[1.42528]$} & {$[0.62613]$} & {$[1.08604]$} & {$[-0.37764]$} & {$[-0.00722]$} & {$[0.00285]$} \\
\hline \multirow[t]{3}{*}{$\Delta$ TSE $(-1)$} & 0.020799 & -0.112006 & -0.445986 & -0.022693 & -0.001958 & 0.029198 & 0.010967 & -0.01941 \\
\hline & -0.03203 & -0.06428 & -0.02504 & -0.03615 & -0.02155 & -0.05453 & -0.05151 & -0.0344 \\
\hline & {$[0.64935]$} & {$[-1.74245]$} & {$[-17.8141]$} & {$[-0.62770]$} & {$[-0.09086]$} & {$[0.53544]$} & {$[0.21293]$} & {$[-0.56405]$} \\
\hline \multirow[t]{3}{*}{$\Delta$ TSE (-2) } & 0.030578 & -0.04934 & -0.326866 & 0.043184 & -0.010374 & 0.09081 & -0.052852 & 0.02898 \\
\hline & -0.03193 & -0.06408 & -0.02496 & -0.03604 & -0.02148 & -0.05436 & -0.05135 & -0.0343 \\
\hline & {$[0.95760]$} & {$[-0.76994]$} & {$[-13.0964]$} & [1.19819] & {$[-0.48295]$} & {$[1.67045]$} & {$[-1.02930]$} & [0.84494] \\
\hline \multirow[t]{3}{*}{$\Delta \mathrm{JCI}(-1)$} & 0.08021 & 0.035137 & -0.02871 & 0.060435 & -0.055384 & 0.060982 & -0.136611 & -0.10044 \\
\hline & -0.03115 & -0.06252 & -0.02435 & -0.03516 & -0.02096 & -0.05304 & -0.0501 & -0.03346 \\
\hline & {$[2.57462]$} & {$[0.56199]$} & {$[-1.17901]$} & {$[1.71866]$} & {$[-2.64256]$} & {$[1.14976]$} & {$[-2.72691]$} & {$[-3.00150]$} \\
\hline \multirow[t]{3}{*}{$\Delta \mathrm{JCI}(-2)$} & 0.057986 & -0.05701 & -0.001139 & 0.082779 & -0.069844 & 0.024116 & -0.071478 & -0.05242 \\
\hline & -0.02289 & -0.04593 & -0.01789 & -0.02583 & -0.0154 & -0.03896 & -0.0368 & -0.02458 \\
\hline & {$[2.53360]$} & {$[-1.24121]$} & {$[-0.06369]$} & {$[3.20447]$} & {$[-4.53629]$} & {$[0.61893]$} & {$[-1.94217]$} & {$[-2.13223]$} \\
\hline \multirow[t]{3}{*}{$\Delta \operatorname{KLCI}(-1)$} & -0.1063 & -0.164186 & 0.072762 & -0.268928 & -0.542375 & 0.061052 & 0.104044 & 0.11107 \\
\hline & -0.04097 & -0.08222 & -0.03202 & -0.04624 & -0.02756 & -0.06975 & -0.06588 & -0.044 \\
\hline & {$[-2.59464]$} & {$[-1.99691]$} & {$[2.27223]$} & {$[-5.81566]$} & {$[-19.6788]$} & {$[0.87532]$} & {$[1.57929]$} & {$[2.52405]$} \\
\hline \multirow[t]{3}{*}{$\Delta \mathrm{KLCI}(-2)$} & -0.109496 & -0.024031 & 0.010039 & -0.123291 & -0.253876 & 0.106493 & 0.129669 & 0.03697 \\
\hline & -0.03822 & -0.0767 & -0.02987 & -0.04314 & -0.02571 & -0.06506 & -0.06146 & -0.04105 \\
\hline & {$[-2.86510]$} & {$[-0.31332]$} & {$[0.33609]$} & {$[-2.85818]$} & {$[-9.87454]$} & {$[1.63675]$} & {$[2.10998]$} & [0.90060] \\
\hline \multirow[t]{3}{*}{$\Delta \operatorname{ISE}(-1)$} & -0.019348 & -0.034765 & -0.006002 & 0.023823 & -0.005084 & -0.71488 & -0.013205 & -0.01237 \\
\hline & -0.01445 & -0.029 & -0.01129 & -0.01631 & -0.00972 & -0.0246 & -0.02323 & -0.01552 \\
\hline & {$[-1.33910]$} & {$[-1.19891]$} & {$[-0.53142]$} & {$[1.46076]$} & {$[-0.52303]$} & {$[-29.0615]$} & {$[-0.56835]$} & {$[-0.79695]$} \\
\hline \multirow[t]{3}{*}{$\Delta \operatorname{ISE}(-2)$} & 0.003622 & -0.002479 & -0.010218 & 0.008083 & -0.023023 & -0.35458 & 0.006128 & -0.02065 \\
\hline & -0.01444 & -0.02897 & -0.01128 & -0.01629 & -0.00971 & -0.02458 & -0.02321 & -0.01551 \\
\hline & {$[0.25086]$} & {$[-0.08558]$} & {$[-0.90554]$} & {$[0.49603]$} & {$[-2.37057]$} & {$[-14.4266]$} & {$[0.26399]$} & {$[-1.33193]$} \\
\hline \multirow[t]{3}{*}{$\Delta \mathrm{EGX}(-1)$} & -0.009855 & 0.00432 & 0.007689 & -0.0791 & -0.00293 & -0.03587 & -0.487687 & 0.00258 \\
\hline & -0.0155 & -0.0311 & -0.01211 & -0.01749 & -0.01043 & -0.02638 & -0.02492 & -0.01664 \\
\hline & {$[-0.63595]$} & {$[0.13890]$} & {$[0.63479]$} & {$[-4.52222]$} & {$[-0.28102]$} & {$[-1.35961]$} & {$[-19.5704]$} & {$[0.15469]$} \\
\hline \multirow{3}{*}{$\Delta \mathrm{EGX}(-2)$} & 0.009579 & -0.000817 & 0.013494 & -0.034619 & 0.004193 & -0.03433 & -0.343476 & 0.00102 \\
\hline & -0.01544 & -0.03098 & -0.01207 & -0.01743 & -0.01039 & -0.02628 & -0.02483 & -0.01658 \\
\hline & {$[0.62047]$} & {$[-0.02636]$} & {$[1.11826]$} & {$[-1.98664]$} & {$[0.40371]$} & {$[-1.30595]$} & {$[-13.8352]$} & {$[0.06169]$} \\
\hline \multirow[t]{3}{*}{$\Delta$ NSE $(-1)$} & -0.02891 & -0.046339 & -0.006553 & -0.121481 & 0.051316 & -0.09209 & 0.025197 & -0.35946 \\
\hline & -0.02422 & -0.0486 & -0.01893 & -0.02733 & -0.01629 & -0.04123 & -0.03894 & -0.02601 \\
\hline & {$[-1.19387]$} & {$[-0.95354]$} & {$[-0.34623]$} & {$[-4.44468]$} & {$[3.15010]$} & {$[-2.23381]$} & {$[0.64709]$} & {$[-13.8207]$} \\
\hline \multirow[t]{3}{*}{$\Delta \operatorname{NSE}(-2)$} & -0.035273 & -0.030238 & 0.004487 & -0.099443 & 0.032571 & -0.03858 & -0.027175 & -0.22723 \\
\hline & -0.02399 & -0.04815 & -0.01875 & -0.02708 & -0.01614 & -0.04085 & -0.03858 & -0.02577 \\
\hline & {$[-1.47018]$} & {$[-0.62800]$} & {$[0.23927]$} & {$[-3.67218]$} & {$[2.01800]$} & {$[-0.94445]$} & {$[-0.70436]$} & {$[-8.81768]$} \\
\hline $\mathrm{C}$ & $-9.57 \mathrm{E}-06$ & $2.05 \mathrm{E}-05$ & $-8.97 \mathrm{E}-06$ & $1.53 \mathrm{E}-05$ & $-9.56 \mathrm{E}-06$ & $-5.66 \mathrm{E}-06$ & $4.41 \mathrm{E}-06$ & $-4.74 \mathrm{E}-06$ \\
\hline & -0.00026 & -0.00052 & -0.0002 & -0.00029 & -0.00017 & -0.00044 & -0.00042 & -0.00028 \\
\hline & {$[-0.03701]$} & {$[0.03951]$} & {$[-0.04437]$} & {$[0.05235]$} & {$[-0.05495]$} & {$[-0.01286]$} & {$[0.01060]$} & {$[-0.01705]$} \\
\hline
\end{tabular}

Significant at $\mathrm{p}<0.05$ 


\section{Conclusions and policy implications}

Market efficiency and financial integration are jointly investigated in this study for D-8 economies. The purpose of the empirical study is to investigate the basic philosophy of constructing this economic group. We used a number of methods for the evaluation of market efficiency, financial integration, and shock transmission as the summarized results are indicating. The random walk hypothesis is tested due to the visualization of arbitrage profits opportunities across the economies; however, it can be earned if the concerned financial markets are efficient at the individual level. Descriptive statistics for D-8 equity market indicates that daily returns of all the equity markets are negatively skewed except Tehran Stock Exchange and Nigerian Stock Market, which reflects that large negative returns are greater than positive returns. Negative asymmetric behaviour is more influential in the negatively skewed markets. Negative shocks have a greater effect than positive shocks. The kurtosis value for Dhaka Stock Market and Egypt Stock Market has higher positive values, which indicate that distributions of returns are leptokurtic and show higher peaks. The performance of the Tehran stock market remained excellent during this period in the set of D-8 economies. The Jarque-Bera test indicates the normality behaviour of all the stock returns. We used serial autocorrelation to test the randomness of returns. Results indicate that return behaviour is predictable and market efficiency does not hold for this selected period. The null hypothesis is rejected for all markets except Istanbul Stock Market. Hence, concluded that ISE is an efficient market from this test point of view. Random walk hypothesis assumes that the log price should have a unit root, whereas the change or returns series must follow the stationarity. Results conclude that time series is non-stationary at the order $\mathrm{I}(0)$ but become stationary at the order I(1) at $1 \%$ and $5 \%$ level of significance respectively. For run test statistics, the null hypothesis indicates that the succeeding price changes move randomly and are not dependent. It is concluded that the return behaviour of KSE, TSE, KLCI, EGX, and NSE are following random behaviour. Runs test for Table 4(b) indicates that the total cases of runs is significantly less than the expected number of runs for all the countries and the KSE, TSE, KLCI, EGX, and NSE and have lower numbers of runs against total numbers of cases and this phenomena rejected the random walk hypothesis and narrates that these markets follow weak form of efficiency. Further, according to Lo and MacKinlay (1988), the variance ratio test is used to test the random walk hypothesis in a more modern way. It is inferred from this statistical test that if the variance ratio test statistics $>1$, the financial time series will be positively associated. The standardized VR test statistics for $\mathrm{z}(\mathrm{k})$ is significant at $\mathrm{J}=2, \mathrm{~J}=4, \mathrm{~J}=8, \mathrm{~J}=12$ and $\mathrm{J}=16$ for all markets. Variance ratio indicates that the equity markets of D-8 countries are efficient based on daily return for the period of 2011-2016. Lo and MacKinlay (1988) identified that the acceptance or rejection of the Random Walk Hypothesis doesn't need to mean that the stock markets are efficient or inefficient respectively in actual spirit because the findings are based on a sample. To test the financial integration, we used correlation test, Granger causality test, cointegration test, error correction model, and impulse response test. Correlation results conclude that no market has a significant relationship with each other. All markets are behaving independently. Further, the Granger causality test indicates that KSE returns leads to the DSE returns significantly. EGX Granger causes to the KSE. JCI Granger causes to DSE whereas DSE Granger causes to JCI, KLCI to TSE and KLCI to JCI, JCI to KLCI, and ISE to KLCI. Trace statistics for cointegration indicates that there exist two cointegrating vectors among these economies. There exist bivariate cointegration statistics between KSE and DSE and identified one co-integrated vector because trace statistics is greater the critical value at none level. Moreover, a result of bivariate cointegration indicates that KSE and DSE markets have a long-run relationship. Short-run relationship indicates that KSE has a significant positive short-run relationship at lag 1 and lag 2 with JCI and negative relationship with KLCI. However, DSE has a positive relationship with KSE, as well at lag 1 and lag 2 , and has a negative significant relationship with KLCE at lag 1 . TSE has a positive relationship with KLCI at lag 1. JCI has a negative relationship with KLCI, EGX, and NSE at lag 1 and lag 2 as well. KLCI has a negative relationship at lag 2 and has a positive relationship with NSE at lag 1 and 2. ISE has a positive relationship with NSE at lag 1. EGX has a negative relationship with KLCI at lag 2 and negative relationship with JCI at lag 2. NSE has a negative relationship with JCI at lag 1 and lag 2 and positive relationship with KLCI at lag 1 . Hence it is concluded that investors can get benefit from the arbitrage process due to market inefficiencies and through the short selling process. Our results coincide with the results of Worthington and Higgs (2004); Hamid, Suleman, Shah and Akash (2010) but are not confirming to the results of Stakic, Jovancai and Kapor (2016), However, Arshad, Rizvi, Ghani and Duasa (2016) evaluated EMH concept that is still a question mark for emerging economies. However, it is improving day by day but developing markets have improved the market efficiency as concluded by Rizvi and Arshad (2017). Further our study also confirms that there exist short-run relationships as expressed by Chung and Liu (1994); Roca (1999); Sheng and Tu (2000); Ng (2002); Lamba (2005); Suchismita and Paramita (2006); Hoque (2007); Hasan and Durrani (2008); Hamid and Hasan (2011) but our study do not confirm longrun relationships among the D-8 economies In recent studies, Almekinders, Fukuda, Mourmouras, Zhou and Zhou (2015), Anwar and Raza (2016) also considered 
the that behaviour of the markets and identified that long-run relationship exists among the KSE-100 index and SSE and KLSE. Results identify that changes in $\mathrm{KSE}$ is due to its own but our study doesn't confirm this hypothesis. Al-Nasser and Hajilee (2016) and Alotaibi and Mishra (2017) also identified that there exist financial integration among the emerging economies. However, the purpose of D-8 economies is not fulfilled to establish a long-run financial integration yet.

Policy implications indicate that financial integration enhances the capital mobilization and provides passage to competitive advantage. Cross board financial integration has become now a significant determinant of financial inclusion after the global financial crisis and financial services and bilateral trade are open for these economies.
Summary of Results for D-8 Equity Markets Market Efficiency

\begin{tabular}{|l|c|c|c|c|}
\hline Markets & $\begin{array}{c}\text { Serial } \\
\text { Auto- } \\
\text { correlation }\end{array}$ & $\begin{array}{c}\text { Unit Root } \\
\text { Test At First } \\
\text { Difference } \\
\mathrm{I}(1)\end{array}$ & $\begin{array}{c}\text { Runs } \\
\text { Test AT } \\
\mathrm{k}=\mathrm{mean} \\
\text { and } \mathrm{k}=0\end{array}$ & $\begin{array}{c}\text { Variance } \\
\text { Ratio at } \\
\text { Return }\end{array}$ \\
\hline Hypothesis & $\begin{array}{c}\text { Efficient } \\
\text { or not }\end{array}$ & $\begin{array}{c}\text { Stationery } \\
\text { or not }\end{array}$ & $\begin{array}{c}\text { Efficient } \\
\text { or not }\end{array}$ & $\begin{array}{c}\text { RWH exit } \\
\text { or not }\end{array}$ \\
\hline KSE & No & Yes & Yes & Yes \\
\hline DSE & No & Yes & No & Yes \\
\hline TSE & No & Yes & Yes & Yes \\
\hline JCI & No & Yes & No & Yes \\
\hline KLCI & No & Yes & Yes & Yes \\
\hline ISE & Yes & Yes & No & Yes \\
\hline EXG & No & Yes & Yes & Yes \\
\hline NSE & No & Yes & Yes & Yes \\
\hline
\end{tabular}

\section{Summary of Results for Financial Integration and Shock Transmission of KSE to Other D-8 Economies}

\begin{tabular}{|c|c|c|c|c|c|c|c|c|}
\hline & & & $\begin{array}{c}\text { Cointegration } \\
\text { Test } \\
\text { Trace }\end{array}$ & $\begin{array}{c}\text { Cointegration } \\
\text { Test } \\
\text { Maximum } \\
\text { Eigen Value }\end{array}$ & Correlation & $\begin{array}{c}\text { Granger } \\
\text { Causality Test }\end{array}$ & $\begin{array}{c}\text { Error } \\
\text { Correction } \\
\text { Model }\end{array}$ & $\begin{array}{l}\text { Impulse } \\
\text { Response } \\
\text { Behaviour }\end{array}$ \\
\hline & & & $\begin{array}{c}\text { Co-integrated } \\
\text { or not }\end{array}$ & $\begin{array}{c}\text { Co-integrated } \\
\text { or not }\end{array}$ & $\begin{array}{c}\text { Correlated } \\
\text { or not }\end{array}$ & Lead or not & $\begin{array}{l}\text { Short run } \\
\text { relationship } \\
\text { exist or not }\end{array}$ & $\begin{array}{c}\text { Shock } \\
\text { transmission } \\
\text { or not }\end{array}$ \\
\hline KSE & $\longrightarrow$ & DSE & Yes & No & No & Yes & No & Yes \\
\hline KSE & $\longrightarrow$ & TSE & No & No & No & No & No & Yes \\
\hline KSE & $\longrightarrow$ & JCI & No & No & No & No & Yes & Yes \\
\hline KSE & $\longrightarrow$ & KLCI & No & No & No & No & Yes & Yes \\
\hline KSE & $\longrightarrow$ & ISE & No & No & No & Yes & No & Yes \\
\hline KSE & $\longrightarrow$ & EXG & No & No & No & No & No & Yes \\
\hline KSE & $\longrightarrow$ & NSE & No & No & No & No & No & Yes \\
\hline
\end{tabular}

\section{References:}

Almekinders, G., Fukuda, S., Mourmouras, A., Zhou, J., \& Zhou, Y. S. (2015). ASEAN Financial Integration. IMF Working Paper, WP/15/34, 1-43.

Alotaibi, A. R., \& Mishra, A. V. (2017). Time varying international financial integration for GCC stock markets. The Quarterly Review of Economics and Finance, 63, 66-78.

Anwar, T., \& Raza, M. Y. (2016). Economic Integration of Stock Markets: An Evidence from Pakistan, China and Malaysia Stock Exchanges. Management and Organizational Studies, 3(3), 2330-5495.

Arshad, S., Rizvi S. A. R., Ghani, G. M. \& Duasa, J. (2016). Investigating stock market efficiency: A look at OIC member countries. Research in International Business and Finance, 36(c), 402-413.

Banerjee, A., Dolado, J. J., Galbraith J. W., \& Hendry, D. (1993). Co-integration, Error Correction and the Econometric Analysis of Non-stationary Data. Oxford: Oxford University Press.

Chung P. J., \& Liu D. J. (1994). Common Stochastic trends in Pacific Rim Stock Markets. The Quarterly Review Economics and Finance, 34(3), 241-259.

Dickey, D. A., \& Fuller, W. A. (1981). Likelihood Ratio Statistics for Autoregressive Time Series with Unit Root. Econometrica, 49(4), 1057-1072.

Fama, E. F. (1970). Efficient Capital Markets: A Review of Theory and Empirical Work. The Journal of Finance, 25(2), 383-417.

Fama, E. F. (1991). Efficient Capital Markets: II. The Journal of Finance, 46(5), 1575-1617.

Granger C. W. J. (1969). Investigating Causal Relationship by Econometric Model and Cross-spectral Methods. Econometrica. 37(3), 424-438.

Granger, C. W. J. (1975). A Survey of Empirical Studies on Capital Markets. In International Capital Markets, Edited by Edwin J. Eltonand, Martin J. Gruber, (North-Holland, Amsterdam), 3-36. 
Hamid, K., \& Hasan A. (2011). Casual and dynamic linkage of stock markets: An empirical study of Karachi Stock Exchange (KSE) with emerging and developed equity markets. African Journal of Business Management. 5(19), 7802-7817.

Hamid, K., Suleman, M. T., Shah, S. Z. A., \& Akash, R. S. I. (2010). Testing the Weak form of Efficient Market Hypothesis: Empirical Evidence from Asia-Pacific Markets. International Research Journal of Finance and Economics, $58,121-133$.

Hasan, A., Saleem, H. M. N., \& Abdullah, M. S. (2008). Long-Run Relationship between an Emerging Equity Market and Equity Markets of the Developed World an Empirical Analysis of Karachi Stock Exchange. International Research Journal of Finance and Economics, 16(1), 52-62.

Hawawini, G. (1984). European Equity Markets: Price Behavior and Efficiency. Monograph Series in Finance and Economics (Saloman Center, New York University).

Hoque, H. A. A. B. (2007). Co-movement of Bangladesh stock market with other markets: Co-integration and error correction approach. J. Manag. Financ., 33 (10), 810-820.

Jin, X., \& An, X. (2016). Global financial crisis and emerging stock market contagion: A volatility impulse response function approach. Research in International Business and Finance, 36, 179-195.

Lamba, S. A. (2005). An Analysis of the Short- and Long-Run Relationships between South Asian and Developed Equity Markets. Int. J. Bus., 10(4).

Lo, A. W. (1997). Market Efficiency: Stock Market Behaviour in Theory and Practice. Vol. I and II, Chethenham, UK. An Elgar Reference Collection.

Lo, A., \& Mackinlay, C. (1988). Stock Market Do Not follow Random Walks: Evidence From a Simple Specification Test" Review of Financial Studies, 1, 41-66.

Mendoza, E. G., Quadrini, V., \& Rios-Rull, J. V. (2009). Financial Integration, Financial Development and Global Imbalances. Journal of Political Economy, 117 (3), 371-410.

Ng, T. H., (2002). Stock market linkages in South- East Asia. Asian Econ. Journal, 16(4), 353-377.

Phillips, P. C. B., \& Perron, P. (1988). Testing for a unit root in time series regression. Biometrica, 75(2), 335-346. Rahman, M. M., \& Shahbaz, M. (2013). Do imports and foreign capital inflows lead economic growth? Cointegration and causality analysis in Pakistan. South Asia Economic Journal, 14(1), 59-81.

Rizvi, S. A. R., \& Arshad, S. (2017). Analysis of the efficiency - integration nexus of Japanese stock market. Physica A: Statistical Mechanics and its Applications, 470, 296-308.

Roca, E.D. (1999). Short term and long term price linkages between the equity markets between the equity markets of Australia and its major trading partners. Appl. Finan. Econ. 9:5, 501-511.

Rounaghi, M. M., \& Zadeh, F. N. (2016). Investigation of market efficiency and Financial Stability between S\&P 500 and London Stock Exchange: Monthly and yearly Forecasting of Time Series Stock Returns using ARMA model. Physica A: Statistical Mechanics and its Applications, 456, 10-21.

Sheng, H. C., \& Tu, A. H. (2000). A study of co-integration and variance decomposition among national equity indices before and during the period of the Asian financial crisis. J. Multinational Finan. Mgt. 10, 345-365.

Stakic, N., Jovancai, A., \& Kapor, P. (2016). The efficiency of the stock market in Serbia. Journal of Policy Modeling, 38(1), 156-165.

Suchismita B., \& Paramita, M. (2006). A Study of Inter linkages between the Indian Stock Market and some other emerging and developed markets. $9^{\text {th }}$ Capital Market Conference Paper, Indian Institute of Capital Markets India.

Sukpitak, J., \& Hengpunya, V. (2016). Efficiency of Thai Stock Markets: Detrended Fluctuation Analysis. Physica A: Statistical Mechanics and its Applications, 458(C), 204-209.

Vavra, P., \& Goodwin, B. K. (2005). Analysis of Price Transmission along the Food Chain. OECD Food, Agriculture and Fisheries. WP 3. OECD Publishing, France.

Worthington, A., \& Higgs, H. (2004). Random Walks and Market Efficiency in European Equity Markets. Global Journal of Finance and Economics, 1(1), 59-78. 